\title{
Notary Role in Making The Farmland Rental Agreement and Sharing Agricultural Land Effort in The District of Mojolaban Sukoharjo
}

\author{
Yuniarto Prasetyo $\mathrm{Aji}^{1}$ and Lathifah Hanim ${ }^{2}$
}

\begin{abstract}
Indonesian agricultural is in changing times in this era, the potential is still carrying out the manufacture of leases of agricultural land and businesses for agricultural crops is still supported by extensive farmland and irrigation as well as the notary's role in the making of a legal entity farmer groups. The purpose of research is to know and analyze the role of the notary in the manufacture of leases of agricultural land and land revenue sharing farming business. Identify and analyze the impact of what happens if there is a dispute in the lease agreement of agricultural land and businesses for agricultural land in the district of Mojolaban Sukoharjo. The result in this research has been done on the role of the notary in the manufacture of leases farmland and effort for the results of agricultural land, agricultural land lease do-written by hand while sharing agreements of farmland and new notaries role in the making a legal entity that is useful to the farmer groups laden capital receipts of the central government.

Keywords: Role of the Notary; Rental Agreement; Profit and Sharing Agreement.
\end{abstract}

\section{Introduction}

Keep in mind one aspect of national development is the increase in economic development. In this case the emphasis on agricultural issues that are part of the development in the economic field, therefore Indonesia is an agrarian country, the largely lived off the land, so the land has a very important position in human life. It sesesuai with the provisions of Decree No. 2 IV / MPR / 1999 on the Guidelines of State Policy, namely:

"Developing a food security system that is based on the diversity of resources foodstuffs, institutional and local culture in order to guarantee the availability of food and nutrition in quantity and quality needed at an affordable price level by taking into account the increase in the income of farmers and fishermen as well as the increase in production is regulated by the law". ${ }^{3}$

The success of agricultural development can not be separated from the success of introducing new technologies to farmers and supporting factors such as the development of irrigation infrastructure, production facilities providers, credit, repair of transportation, etc. The activity of that nature involving many parties, namely the government through institution relevant agencies, the private sector and farmers themselves as the spearhead of agricultural development to derive optimal benefits

\footnotetext{
${ }^{1}$ Master of Notary's Student Sultan Agung Islamic University (UNISSULA) Semarang email yuniarto.prasetyo@gmail.co.id

2 Lecture of Faculty of Law UNISSULA

1) MPR Decree No. 2 IV / MPR / 1999. Garis-garis Besar Haluan Negara Sinar Grafika Jakarta p. 19.
} 
from agricultural land, there must be a good and continuous cooperation between farmers and the government. Especially if the government wants to take out a policy governing the relationship with farmers, the government should save farmland from being used for residential, enterprise, or for activities other than agriculture. So that government acts in accordance with the vision and mission of the guidelines that it accelerate rural development in order to empower people, especially farmers and fishermen through the provision of infrastructure, agribusiness systems development, small industry and handicrafts, institutional development, mastery of technology and utilization of natural resources.

Here the author takes the title role of the notary in the manufacture of leases farmland and effort for the results of agricultural land in the district Mojolaban Sukoharjo. By narrowing the research titles aimed so that researchers can conduct research and sufficient time available to complete the study, as in his book Mardali S, said that the selected title is able to carry out research ${ }^{4}$.

Tenancy agreement is already regulated in Act No.5 of 1960 On the Agrarian Law, in particular Article 10 paragraph (1) the contents Every persons and legal entities that have rights over agricultural land in principle obliged to work or actively working on it alone, by preventing the ways extortion to cope with one of the parties let nobody feel aggrieved, it would be nice if the leases of agricultural land is done in writing before Public Notary Law. Its mean get certainty by the laws of the Republic of Indonesia Number 2 of 2014 on the Amendment of the Act No.30 of 2004 concerning Notary is a public official authorized to make an authentic agreement and other authorities referred to in the legislation ini.Di in the implementation of leases of agricultural land at this time is actually the role of the Notary is needed by the tenant with the parties rents in order to obtain legal certainty, peace of both parties who have entered into a lease of agricultural land. This aims to protect both parties in order to implement the rights and obligations of each well and correctly in accordance with the agreement that has been made.

The purpose of his research are: 1 . To know and analyze the manufacture of leases of agricultural land and businesses for agricultural land in the district of Mojolaban Sukoharjo. 2. To identify and analyze public notary role in the manufacture of agricultural land and businesses for agricultural land in the district of Mojolaban Sukoharjo. 3. To know and analyze the impact of what happens if there is a dispute lease agreement of farmland and effort for the results of agricultural land in the district of Sukoharjo Mojolaban.

\section{Research Methods}

The approach used in this study is the sociological juridical approach, to obtain primary data and find out the truth by using inductive thinking method and criterion of truth correspondent and facts used to perform the induction process and testing truth correspondent. ${ }^{5}$ This method is an approach to the methods of approach to positive legal regulations and seen in practice in the community.

\footnotetext{
4) Mardalis 1995 Metodologi Penelitian Bumiaksara Jakarta p.34.

${ }^{5}$ Soerjono Soekamto \& Sri Mamuji 2001. Penelitian Hukum Normatif (Suatu Tinjauan Singkat)

Rajawati Pers Jakarta. p.14
} 
Methods of data collection research using Primary Data Primary data is data obtained directly on the ground that in this case the authors obtained directly and sourced from interviews, the notion of an interview is a way of collecting data by asking directly to the informant or the competent authorities on issues ${ }^{6}$. And other sources, secondary data source is a data source that does not directly provide information and complementary source of primary data, secondary data generally have been arranged in the form of legislation, papers, in the form of books, journals, articles and theses.

In this study the authors use qualitative data analysis. Qualitative analysis is actually a research procedure that produces descriptive data that is what is stated by the respondent in writing or verbally, qualitative analysis is done by means gather the data that have been obtained are then linked with the theories related to the problems examined.

\section{Results And Discussion}

From the results of research conducted by the author with the mrs. Tanti as an extension field district of Mojolaban Sukoharjo on Wednesday, 23 May 2018, at 10:00 am, explaining the role of the notary in the manufacture of leases farmland and effort for the results of agricultural land in the district of Mojolaban Sukoharjo, that the agreement is carried out under customary law are less able to ensure legal certainty in the manufacture of leases of agricultural land and venture agreement for the results of a culture of mutual cooperation and mutual trust and agreement 'things are going on the basis of kinship and mutual help '.

Description mrs. Tanti as a counselor in the district Mojolaban, describing the leases farmland and effort for the results of agricultural land in the district Mojolaban is Due to the large land owned so the lack of time to work, Feeling no longer able to work due to the influence of age (old) and state of health, because the difficulty of finding water in the dry season and the difficulty of finding workforce.

Form of revenue-sharing agreements in Mojolaban usually people use Oral Agreement, is considered more practical than using a written agreement, but if the lease of agricultural land form of the agreement made in writing and term of leases of agricultural land on average 1 year, while the agreement the results of the agricultural land is usually not determined by both parties.

Notary role in farmer environment according to mrs. Tanti is only limited tanti-making entity for farmer group and the establishment of PT, the functions from regulatory agencies gakpotan it is laden to receive assistance from the government, especially the capital. If it's in the manufacturing and business lease agreement for the result between farmers and landowners, among the tenants with people who are renting. The role of the notary here is not maximized, whereas here educator has often reminded the farmers to hold agreements written in order to obtain legal protection and legal certainty if an agreement with the company if the farmland hired by companies to test drugs, fertilizers and crop seeds.

According mrs. Indri as a representing the PT.Biotek Agri Lestari is engaged in the lease of agricultural land and cooperation with the Agreement of Establishment No. 01 dated 05 May 2017 made before Fitri Wahyu Wibowo, SH, Mkn, Notary in Karanganyar

${ }^{6}$ Sugiarto Dergibson Siagian Lasmono Tri Sunaryanto Deny Soetomo 2001 Teknik Sampling Jakarta Gramedia Pustaka Utama p.17. 
explained that the reason for doing the tenancy agreement and cooperation of agricultural land devoted to market fertilizer products to farmers and to guarantee a supply of Mentik Susu Rice ( Javanese lang.) which is the flagship product of PT.Biotek Agri Lestari, the shape of the tenancy agreement and cooperation of agricultural land written and there are witnesses, the term of the agreement is not determined exactly, but at least 1 year or 3 times the harvest, counterweight to the results or the top of the result of the cooperation is the cost of production (pre-planting) is cut from the sale of grain to record planting rice farmers and the Mentik Susu Biotech will purchase the harvest with a difference of $500 / \mathrm{kg}$ at a price. In order that farmers have the right among others, are entitled to receive payment of the harvest of grain, after deducting the costs of procurement of seeds, fertilizers and pesticides, receive training, counseling and mentoring program of cooperation, to seeds of rice varieties Mentik Susu, in addition to the right, the farmer has an obligation, among others, provide land for where rice cultivation, planting rice milk varieties Mentik Susu at least 20 rice seed planting, maintenance and harvesting. Submit and sell the entire production / harvesting grain to the first party at the time specified by based on the market price at that time or based on a price agreement that has been established and agreed upon by the parties. Follow and comply with the partnership program organized by the first party. Report to the first side constraints encountered during the use of biotech products Decomposers each end of the harvest, assign it to the heirs or their proxies when unable to remain or passed to continue the partnership and cooperation agreement receives payment results as evidenced by a signed power of attorney over the seal. Follow and adhere to the partnership program organized by the first party, reporting to the first obstacles encountered during the use of products Biotech Decomposers each end of the harvest, assign it to the heirs or their proxies when unable to remain or passed to forward agreements and partnerships to accept the result of the payment as evidenced by a signed power of attorney over the seal. Follow and adhere to the partnership program organized by the first party, Reporting to the first obstacles encountered during the use of products Biotech Decomposers each end of the harvest, assign it to the heirs or their proxies when unable to remain or passed to forward agreements and partnerships to accept the result of the payment as evidenced by a signed power of attorney over the seal.

And venture agreement for the results of the agricultural land is done by Oral Agreement because it has always been done by Oral Agreement and based on mutual trust between the land owner with tenants, usually both parties knew each other. The citizens are not familiar with the Act No.2: 1960 is already familiar with Islamic law notary's role here is merely authorize legal entities to gapoktan because it serves to condition the receipt of funds / capital from the government.

The timing of the agreement for lease of agricultural land is determined approximately 1 year if they fit the usual extended again, whereas venture agreement for the results are not determined exactly as long as they want to work are welcome to work on. Counterweight to the results, the balance of which is used by agreement of both parties. usually in the region of hamlet using half division. Landowners rights, entitled to receive a cash payment for the lease of agricultural land as agreed, entitled to take the land if an agreement has been disconnected. Obligations of landowners, obliged to pay the tax, Obliged to cede land to the tiller. Tenants rights, Getting $1 / 2$ of parts that have been signed. Tenant obligations, caring farmland as well as possible. Restoring 
the original condition of the ground as if the agreement had been finished. Lease land right, eligible to receive money on payment of land rent. Liabilities people who lease land, Obliged telling the truth about the condition of agricultural land. Tenant rights, entitled plots of land to the maximum until the agreement expires, Eligible for comfort while working on a farm. Obligations of tenants, pay according to the agreed price, pay taxes. Appears problems that arise in the tenancy agreement the tenant of agricultural land does not return to its original state as the size of rice paddies (if want to fertilize). Problems arising in venture agreement for the results related to money tleser (cutlery rice).

From some statements of respondents can be concluded that the role of the notary in the manufacture of leases of agricultural land and businesses for agricultural land in the district Mojolaban Sukoharjo. That the making of leases of agricultural land is done by writing and venture agreement for the results Oral Agreement according to the customs and on the basis of trust and familiarity. The term of the lease agreement for an average of 1 year and for sharing agreement is not determined for certain duration. While the role of the notary in the manufacture of leases farmland and effort for the results of new farmland here in the manufacture of a legal entity farmer groups.

From the description of Mr. and Mrs. PPL (Field Practice Student) and the farmers in the research area shows that the role of the notary in the manufacture of leases farmland and effort for the results of agricultural land in the Mojolaban Sukoharjo is not actively involved towards making the leases of agricultural land and business for farmers. The results in the manufacture of leases of agricultural land just a written agreement under hand and venture agreement for the results in Oral Agreement, while new notary role contributes to the making of a legal entity farmer groups (gapoktan), it do not all farmer groups incorporated. Considering Act No.23 of 2014 on local governments, said each institution, group, or organizations that receive grants from the government must be a legal entity, here the role of the notary in the manufacture of very important legal body. This is done so that the farmer groups receive legal protection, coaching and facilities from the government to both members and managers, basically the policy is not difficult for the farmer groups but even more to the precautionary principle in order to avoid violations of the law that resulted in problems later in life, both the government and the farmers. The bottom line for farmers even better, because by having a legal entity (legality) they become more powerful and believable and easy in a variety of administrative arrangements. As well as functions as a single economic unit that has the ability to get profit.

\section{Closing}

\subsection{Conclusion}

Based on these discussions, it can conclude the following authors:

- In the manufacture of leases of agricultural land in the district of Sukoharjo Mojolaban mostly use the form of written agreement it is caused because they want to get legal certainty in agreement. Different with venture agreement for the results of the agricultural land in the district of Sukoharjo Mojolaban most of them use Oral Agreement or not writing this is because they are many who do not know the Act. No. 2 of 1960.

- Factors that influence the making of the tenancy agreement and effort for the results of agricultural land in the district of Mojolaban Sukoharjo caused by the lack 
of time to work on their own land optimally although still strong, because of the ground it has, because it is old, and when the season dry where it's rather difficult to find water.

- Preparation of the tenancy agreement and effort for the results of the agricultural land in the district of Sukoharjo Mojolaban was not in accordance with the Act No. 2 of 1960 which states that the agreement is made in writing and term of the agreement had been predetermined. While in practice Oral Agreement done deal and the time period is not predetermined. In contrast to the manufacture of lease agreements with businesses farmland for agricultural crops, manufacture Here leases of agricultural land be made in writing and term of the agreement has also been determined in advance.

- Regarding the term of the lease of agricultural land was done approximately one year while the business for the produce is not specified at all. And about sharing the land in the district of Mojolaban is $1 / 2,1 / 4$

- The role of the notary in the district of Sukoharjo Mojolaban apparently not functioning optimally, merely in making legal entity farmer group (gapoktan) not towards content creation leases of agricultural land and the establishment of PT. engaged in agriculture alone.

\subsection{Suggestion}

- Require counseling to both the village and sub-district officials, this was due to a recording among many who do not know about the Act No. 2 of 1960.

- Conducting outreach to the community, especially the landowners and tenants as well as tenants, to want to perform the agreement in writing, at a minimum, created under the hand klau made an agreement before a Public Notary that did not want to.

\section{References}

[1] Mardalis 1995 Metodologi Penelitian Bumiaksara Jakarta.

[2] MPR Decree No. 2 IV / MPR / 1999. Garis-garis Besar Haluan Negara Sinar Grafika Jakarta.

[3] Soerjono Soekamto \& Sri Mamuji 2001. Penelitian Hukum Normatif (Suatu Tinjauan Singkat) Rajawati Pers Jakarta.

[4] Sugiarto Dergibson Siagian Lasmono Tri Sunaryanto Deny Soetomo 2001 Teknik Sampling Jakarta Gramedia Pustaka Utama.

[5] Law of the Republic of Indonesia Number 2 of 2014 concerning The Amendment of Act No. 30 of 2004 Concerning The Position Notary

[6] Act No.2 1960 on Sharing 